\title{
THERE ARE NO EASY COUNTEREXAMPLES TO LEGAL ANTI-POSITIVISM
}

\author{
Emad H. Atiq
}

I

EGAL POSITIVISTS and anti-positivists disagree about the grounds of law. They disagree about what at the most fundamental level it is in virtue of that a rule gets to be a legal rule.

Positivism is the view that the ultimate grounds of legality are social in nature. They concern the social properties of rules: roughly, having to do with a community's attitude of acceptance towards a rule, or its acceptance by key officials. There are variations on this general theme, but positivists stand united in their commitment to instances of fundamental legality - the legality of the fundamental legal rules - being grounded exclusively in the social features of those rules. The fundamental legal rules are ones which are not themselves "derived" (in a sense that stands in need of precisification) from other legal rules. For example, according to Hart, legal systems are systems of hierarchically structured rules. There are higher-order "rules of recognition," which legal officials accept and follow. These higher-order rules determine the conditions under which first-order rules specifying outcomes for particular situations count as law. The legality of first-order rules thus derives from rules of recognition. ${ }^{1}$

The disagreement within the positivist camp concerns the grounding of non-fundamental legal rules - those derived from more fundamental ones. "Inclusive" positivists allow that the moral features of a derived rule may be part of the explanation for why it is law, but only if a higher-order legal rule, whose legality is grounded in its social features alone, entails the legality of the derived rule on the basis of the latter's moral features. ${ }^{2}$ Imagine a jurisdiction whose legal officials have collectively adopted a general convention of enforcing whatever fine-grained rules for practical situations are morally optimal. The conventionally embraced general rule of enforcement is legal solely on account of its social features-namely, its conventionality. But the more fine-grained sit-

1 Hart, The Concept of Law. Cf. Austin, The Province of Jurisprudence Determined; Raz, The Authority of Law; Marmor, Philosophy of Law; and Shapiro, Legality.

2 Waluchow, Inclusive Legal Positivism; Coleman, The Practice of Principle. 
uational rules (e.g., a rule dictating when promises are to be enforced against a promissor) may earn their legality partly based on their moral features. The "exclusive" positivist agrees that the higher-order rules may direct legal officials to rely on moral considerations in deciding what the law is, but denies that this means the moral features of rules ground instances of law, whether the legal rules in question are instances of derived or fundamental legality. These internecine disagreements among positivists can be largely ignored in what follows, but I will discuss them as they become relevant to the argument.

Anti-positivism is the view that a rule's moral features ground its legality fundamentally. The social features of rules matter, but so does the morality of rules. For example, according to traditional varieties of anti-positivism, unless a rule is one we morally ought to obey, or is consistent with moral principles that maximally justify our social practices, the rule cannot be legal. And this fact is not itself explained by any higher-order legal rule whose legality is grounded in social conventions or anything of the sort. Law depends fundamentally on morality's sanction.

\section{THE EXTENSIONAL CHALLENGE}

Positivists claim that there are straightforward counterexamples to anti-positivism involving rules that bear all the hallmarks of legality but that are not by any stretch of the imagination ones we morally ought to obey or compatible with the basic principles of justice. Among other things, the Third Reich promulgated legal rules requiring the outright exclusion and ultimate extermination of Jews and other minorities in Nazi Germany. Nazi law was genuine law. In antebellum America, the Fugitive Slave Act required the return of a runaway slave to their master. The Fugitive Slave Act, morally grotesque though it was, was bona fide law. ${ }^{3}$ It is easy to multiply examples of morally objectionable rules that clearly are laws of states (e.g., California had a "three-strike" rule, mandating life imprisonment based on three criminal convictions regardless of gravity). But if anti-positivism is true, these rules cannot be law. They might be conventionally followed. But their severe moral defects preclude their legality.

Nazi law, the Fugitive Slave Act, the three-strike rule in California are actual cases of law mobilized as counterexamples to anti-positivism. But there are also possible cases of law that present an extensional challenge. Consider a scenario offered by Marmor. ${ }^{4}$ Marmor imagines a community in which individuals sin-

3 See discussion of the Fugitive Slave Act in Dworkin, "Hard Cases" and "Natural' Law Revisited"; and Shapiro, Legality, ch. 1.

4 Marmor, Philosophy of Law, ch. 2. 
cerely believe that (and act as if) a rule is law: they follow it, they sanction deviations from it, they call the rule "law," they think it is a good thing the rule is law, and so on. We can stipulate that all the external trappings of a legal system are present (there are courts, police, and a legislative body, for example). If the anti-positivist is right, it is possible for everyone in the community to be mistaken about their favored rule's legality. After all, the rule might be immoral—say, one that demands a human sacrifice every New Year's Eve. But, surely, the community cannot be systematically mistaken about the rule's legality. Yet another false negative.

Anti-positivism's perceived extensional inadequacy explains why positivism is the dominant position in legal philosophy, or at least why it is so often portrayed as such. To deny that the Nazis had law, that the Fugitive Slave Act was law, that Marmor's hypothetical society could not possibly be in error, is counterintuitive.

Anti-positivists have offered two types of responses to this extensional challenge. The first charges the critique as question begging. To assume anti-positivism's negative results are false negatives assumes the falsity of anti-positivism. Anti-positivism just is the view that an "unjust law is not law." So, contrary to what positivists tell us, the Nazis did not have laws, the Fugitive Slave Act was not law, and communities can be systematically mistaken about their own laws.

To repeat, this is a hard position to maintain. While it would indeed be question begging to assume anti-positivism is refuted by simply pointing to these cases of apparent legality, the problem for the anti-positivist is that it is very hard to explain away (as widespread error) judgments made by a diverse range of experts and nonexperts about law. ${ }^{6}$ The legality of Nazi rules is intuitive. And the intuition is pre-theoretical. Individuals unexposed to the debate between positivists and anti-positivists find it natural to say that Nazi Germany had a legal system (with abhorrent legal rules). If anti-positivists can do no better than deny the legality of morally abhorrent rules without plausibly explaining why widely shared intuitions are mistaken, anti-positivism is deservedly characterized as the more counterintuitive position.

The second response, offered by most modern anti-positivists, draws on the fact that the morality of legal rules (or entire legal systems) can be influenced by

\section{Aquinas, Summa Theologiae.}

6 Finnis, Natural Law and Natural Rights, is sometimes interpreted as suggesting that Nazi law is only law in an analogical sense. We say Nazis had law because their rules bear resemblance to the focal genuine cases of law which are morally good rules. But this is just to deny the intuition underlying the extensional challenge: that the Nazis had law, not something that merely resembles law. 
our social practices. A rule's legality is grounded not in its being morally obligatory. Rather, it is grounded in its compatibility with justice taking into account our social practices. For instance, Dworkin suggests that rules have the property of being law only if they "figure in or follow from the principles of justice, fairness, and procedural due process that provide the best constructive interpretation of the community's legal practice." Famously, Dworkin thinks that in figuring out what the law is, judges face the Herculean task of first figuring out which general principles would morally justify, as far as possible, what we do around herethat is, our social practices. His view allows that there might be aspects of our social practices that morality could never justify, that might be irredeemable from the moral point of view. But the content of the law are those rules and principles derived from social practices that are compatible with the optimific moral principles, the ones which maximally justify how we do things around here. ${ }^{8}$ Likewise, Greenberg holds that law is the change in our "moral obligations" driven by our social conventions. ${ }^{9}$

These modern refinements to anti-positivism allow law and morality to come apart. The rules we morally ought to obey simpliciter may be quite different from the ones we morally ought to obey in light of our social practices. The latter might be, all things considered, morally inferior, and we might have moral reason to follow them anyway because they represent the rules we have democratically elected to follow. Rawls's arguments for compromising on what is morally best in the interest of living on reasonable terms with parties who do not all share the same comprehensive moral theory provide a helpful (yet neglected) comparison to Dworkin's view and views inspired by Dworkin. ${ }^{10}$

Although modern versions of anti-positivism allow legal rules and morally optimific rules to come apart, they cannot accommodate dramatic departures

7 Dworkin, Law's Empire, 225 (emphasis added).

8 An anonymous reviewer suggests a better interpretation of Dworkin regards the social practices as "raw material" that is morally interpreted. Dworkin's view is indeed sometimes understood by analogy with morally interpreting a work of fiction, where the "morally best" version of Huckleberry Finn is one which portrays the events of the novel, the characters, and so on in their morally best light. But I doubt this is the best of way understanding Dworkin. Dworkin is interested in the moral facts governing what individuals should do and how these facts might be shaped by social practice. In any event, this alternative interpretation does not immunize the Dworkinian from the counterexamples, as I explain below.

9 Greenberg identifies law with our actual moral obligations that have been shaped by social practice. He self-conceives as articulating Dworkin's considered/developed view and cites personal correspondence as evidence that Dworkin agrees ("The Moral Impact Theory of Law," 1301n28). 
of law from what is morally required. ${ }^{11}$ Dworkinian anti-positivism might accommodate the occasional immoral rule as genuine law in a community, like the three-strike law of California. But it cannot accommodate Nazi law. It is entirely implausible that the morally best reconstruction of the conventions and practices of the Third Reich would recognize as law rules calling for the murder of Jews in Nazi Germany. ${ }^{12}$ Our conventions-what we do around here-plausibly make some difference to what rules we should follow in light of the principles of justice and fairness. ${ }^{13}$ But they cannot make the kind of difference which would allow anti-positivists like Dworkin and Greenberg to recognize the laws of Nazi Germany as bona fide laws. Likewise, by no stretch of the imagination were the rules dubbed legal by judges who upheld the Fugitive Slave Act ones we had a moral obligation to obey in light of social practice.

Marmor's challenge also still stands. It remains possible for an entire community to treat a set of rules as law that are not the morally best rules for the community to follow given its habits, conventions, and practices. And if it is impossible for an entire community to be mistaken about its accepted laws, then modern versions of anti-positivism are just as vulnerable to Marmor's extensional challenge.

\section{THE NORMATIVITY OF ABHORRENT LEGALITY}

Morally grotesque legal rules may be counterexamples to parochial forms of anti-positivism. But they are not necessarily counterexamples to anti-positivism. Anti-positivism in the most general sense is just the view that the fundamental grounds of law include moral facts: a rule's being law is partly grounded in its moral properties. In addition to what I have called optimific moral properties-

Alexy, "Legal Certainty and Correctness": "Not every injustice, but to be sure extreme injustice is not law" (444-45).

The Dworkinian denies the legality of Nazi rules. Even if we construe Hercules as engaged in a kind of moralistic interpretation of the social practices of Nazi Germany, it is entirely implausible that there is a morally best or redemptive story of Nazi Germany, a society where the socially embraced rules call for genocide. And even if there were one, it would not sanction the legality of the genocidal rules. Dworkin's Herculean judge is certainly willing to dismiss large numbers of judges in the United States as straightforwardly wrong about the law, e.g., judges who upheld the Fugitive Slave Act, because they failed to recognize the legality of the principles which would morally justify (as much as possible) what we do around here, consistency with which is a condition on the legality of any rule (Dworkin, "Hard Cases" and "The Law of the Slave-Catchers"). So, the counterexamples apply with full force.

13 On the moral significance of conventions generally, see Mavrodes, "Conventions and the Morality of War." 
being morally best, being what ought to be done, being required by the principles of justice, and so on-there are moral properties that come in degrees, like the property of being morally good to some degree, or the property of being supported by a moral reason. Correspondingly, there are moral facts involving such weak or gradable properties, like the fact of a rule's being such that there is some moral reason to follow it.

Traditionally, anti-positivists have attempted to ground law in the optimific moral properties of rules. A rule's being law is grounded in its being the morally best rule to follow, or in its being consistent with moral principles that maximally justify community conventions. But gradable moral properties can serve as possible grounds of law. Arguments for anti-positivism properly understood support this possibility, as I explain shortly. So long as a rule's legality can be grounded in the existence of some moral reason to follow it, the anti-positivist can accommodate the legality of any rule recognized as clearly legal by the positivist. For if a rule is law and its legality is consistent with positivism, then the rule is conventionally followed or accepted in the community by key officials. ${ }^{14}$ And (I argue) if a rule is widely accepted, then quite plausibly there is always some moral reason for agents to follow it, albeit a very weak reason.

Consider the rules of the Third Reich. The fact that morally grotesque rules involving state-sanctioned terror were widely accepted and enforced against persons entails some extremely weak and easily missed moral reasons for persons to obey them. There are, for example, reasons of self-protection. Deviating from conventionally embraced rules renders individuals vulnerable to sanction. The reasons of self-interest that individuals have for obedience are, I submit, moral reasons. While self-interest can be amoral or even immoral when an agent is disproportionately sensitive to her own interests to the exclusion of others, concern for one's self can also be perfectly ethical, insofar as every person's interests matter from the impartial point of view.

While positivists sometimes acknowledge the existence of normative reasons to follow conventionally embraced rules, they neglect the moral character of such reasons and the conceptual possibilities they open up for anti-positivists. ${ }^{15}$ Admittedly, the moral character of reasons to protect and promote one's

14 As I explain below, even rules derived from higher-order rules of recognition enjoy a kind of acceptance by legal officials, given a plausible view of what it is for legal officials to follow or be committed to a higher-order legal rule. However, the "easy" counterexamples I have discussed in this paper and am primarily interested in disarming involve rules that are widely embraced, and not just by a handful of legal officials.

15 Raz, The Authority of Law; Marmor, Philosophy of Law; Shapiro, Legality. 
interests is not obvious. Neither is it uncontroversial. ${ }^{16}$ Yet the arguments in favor of the proposition seem to me to be overwhelmingly plausible, even if it remains true that not all prudential reasons are moral reasons, and that not all cases of self-regarding action involve responsiveness to moral reasons.

One argument for the moral nature of the relevant class of reasons appeals to the character of an agent's motives for self-protection. The connection between motivational experience and evaluative facts is widely recognized. For example, the ethical intuitionist takes motivational and affective experience to involve direct perception of bona fide evaluative facts. ${ }^{17}$ While not just any motivation could possibly constitute awareness of moral facts, it is awfully tempting to think that the evaluative facts made manifest by agent-neutral empathic motivationinvolving desires that are both "impartial" and "welfarist"-are moral in nature. A desire is impartial if it does not turn on (is not sensitive to) the identities of agents. ${ }^{18}$ If a desire is welfarist, then it favors states of affairs which contribute to individual well-being. If this is right, then there can be moral reasons to promote one's own interests because it is possible to be impartially concerned about one's own pains and pleasures. This form of concern involves seeing the pains as worth diminishing not because they are one's own. It involves seeing the pains as repellent and the pleasures as attractive in an "identity-independent" way. ${ }^{19}$ An identity-independent or impartial desire to diminish or avoid pains (especially the pains one is intimately acquainted with) involves appreciating (or judging) a paradigmatic moral truth: it seems to me that there is moral reason to avoid the pain, insofar as I am able to. This reason invites us to show similar concern for the pains of others and may serve as a normative foundation for a broader (and more recognizably moral) concern for general welfare. ${ }^{20}$

16 Reasons of self-interest are often contrasted with other-regarding moral reasons. The former lack the obligatory or "deontic" force of more familiar varieties of moral reasons (Raz, Engaging Reasons; Little and McNamara, "For Better or Worse"). But this contrast does not show that the reasons of self-interest are a nonmoral species of reasons. See Munoz, "All Reasons Are Moral," which argues that the contrast in felt "oomph" can be explained in terms of an absence of countervailing reasons in the case of deontic moral reasons, along with the concept of a moral prerogative. In any event, the central issue is not whether the reasons are moral (though they are), but whether they are genuinely normative (which they are as well). For meta-normative background, see notes 20 and 30 below. Cf. Johnston, "The Authority of Affect." Hare, The Language of Morals; Atiq, "Supervenience, Repeatability, and Expressivism." Are some forms of partial concern moral (e.g., concern for Helen just because she is Helen)? I doubt it. Partiality is at best morally permissible. But I do not defend that claim here. The above argument relies on a modest assumption: moral reasons are at least those reasons appreciable from an impartial welfarist motivational perspective. 
The moral reasons of self-protection are reasons to follow even Nazi laws. But it would be perverse to overstate the case. While there may be some (non-decisive) moral reason to follow a rule that causes extreme harm to others, that reason is vastly outweighed by competing considerations that militate against obedience. ${ }^{21}$ So, a German citizen might have had overwhelming moral reason to resist the laws of Nazi Germany, but this would not diminish the moral fact that she had some (albeit very weak) moral reasons, having to do with the good of self-protection (impartially construed), for following Nazi rules. ${ }^{22}$

evaluative judgment. This connection has been emphasized by (among others) quasi-realist expressivists (cf. Blackburn, Spreading the Word; Gibbard, Thinking How to Live), a group to which I belong; and ethical intuitionists of the sort who treat all (most?) desire and affect as normative "seemings" or perceptions of bona fide value (cf. Johnston, "The Authority of Affect," and, on one interpretation, Scanlon, What We Owe to Each Other). As a quasi-realist, I take normative judgements to be wholly constituted by desire-like attitudes. We use normative language to express these attitudes, and our linguistic practice guarantees the existence of real normative properties (as well as normative truths, propositions, and so on; cf. Schiffer, The Things We Mean; Thomasson, Ontology Made Easy). It seems plausible that there are phenomenally (and otherwise) distinguishable varieties of noncognitive attitudes (cf. Johnston, "The Authority of Affect"), and that there are distinct varieties of normative properties and facts corresponding to these different ways of being motivated, with moral facts associated, at a minimum, with empathic motivation. The quasi-realist basis for thinking this is the fact that we can introduce normative predicates in our language based on finegrained distinctions between desire-types and their expression (consider the legal ought versus the moral ought); and there are properties corresponding to these predicates for the usual "easy" ontological reasons (cf. Schiffer, The Things We Mean). I realize this is extremely breezy. But the paper is not intended as general metaphysics and meta-normative theory. I say all this merely as theoretical background for the normative claims and arguments I am making (arguments one need not be a quasi-realist to accept).

21 I take this to be a case of normative outweighing and not defeat. If the severe moral defects of a rule defeat any reason to follow the rule, then there are not any reasons to follow morally abhorrent rules. I submit that the force of the reasons of self-protection to follow abhorrent rules remains appreciable from a motivational point of view of impartial empathy. One's own pains do not lose their disvalue-and the impulse to stop or prevent the pain does not diminish-in the light of the pains of others. The self-protective impulse is overcome, in the virtuous, by a stronger impulse to do justice and act impartially in the interests of all. But it is not extinguished. This is apparent from the fact that it seems appropriate for the virtuous to sympathize with their own suffering, even as they engage in acts of self-sacrifice supported by the weight of their reasons. Contrast a case of genuine normative defeat: the moral reason to promote someone's pleasure is extinguished by their acting wrongfully, given plausible desert-based normative principles. The wrongdoer's pleasure no longer presents as appealing in the light of serious wrongdoing.

22 An anonymous referee suggests a society of lunatics with suitably bizarre conventions may prove challenging for my view. The relevant rules may be widely accepted, and yet it would not be in anyone's prudential self-interest to follow them. I suspect even bizarre but conventionally embraced rules will generate extremely weak moral reasons for some agents to 
Accordingly, Nazi law is not an example that is per se inconsistent with anti-positivism. If there is a viable version of anti-positivism on which instances of abhorrent legality are partly grounded in weak moral reasons for obedience, it would avoid the counterexample. And we will see in a moment that there is indeed a viable view which takes this form. The point for present purposes is simply to identify the relevant moral facts in which the legality of morally abhorrent rules might be grounded. (If the emerging strain of anti-positivism appears too watered down to be interesting, such concerns should be set aside for the time being. I explain in section 3 why this particular grounding claim is entailed by a promising general theory of law that is consistent with the principle motivations for being an anti-positivist, that captures the unity of the concept of law, and that explains how the social and moral characteristics of rules work together to ground their legality. The present aim is simply to clarify the scope of the alleged counterexamples.)

Consider Marmor's hypothetical. Marmor suggests that anti-positivism entails that a community might be systematically mistaken in its treatment of rules as law. But anti-positivism does not entail this. The force of the hypothetical turns on the assumption that moral properties that ground law according to the anti-positivist must always be optimific. If the legality of rules is always grounded in their moral optimality (whether relativized to social practice or not), it is possible for law and people's treatment of a rule as law to come apart. But so long as we have gradable moral properties in the picture, we see that a rule that the community treats as law is guaranteed to have some moral property: the property of being good to follow to some degree. And so, an anti-positivist willing to ground some instances of legality in weak moral reasons may agree with Marmor about the impossibility of error, while disagreeing about its explanation.

Why does conventional acceptance of a rule's legality entail some normative reasons, moral or otherwise, to follow the rule, even if there is no moral obligation? As before, the widespread acceptance of a rule entails a prudential interest in following it, which ensures the existence of some moral reasons for obedience. Moreover, acceptance of a rule arguably involves having a desire or pro-attitude toward following it. ${ }^{23}$ While by no means uncontroversial, it is a viable ethical position that there is always some reason to perform an action whenever one

follow them (see discussion below concerning reasons grounded in subjective attachments). But it is also worth noting that the legality of such fanciful rules is less obvious than the primary cases discussed. In section 4, I discuss what makes for an "easy" counterexample to anti-positivism.

23 Woods, "The Authority of Formality." 
desires it. ${ }^{24}$ The overwhelming weight of reasons that speak against the satisfaction of certain perverse desires should not be confused with the state of there being no reason whatsoever (moral or otherwise) for satisfying them. There are other, related, reasons for following conventionally accepted rules of a broadly "Humean" variety, which derive from an agent's attachment to tradition or conventional ways of doing things - a desire to keep doing how we do things around here. ${ }^{25}$

It bears emphasizing that the moral (and broadly normative) facts that, I am suggesting, might ground morally grotesque legal rules are limited in scope. The claim is not that every agent subject to a legal rule has reasons to follow the rule. The identified reasons for following abhorrent rules will not apply to agents who can break laws without consequence or those who fail to have any attachment or professional commitment to conventionally embraced rules. Anti-positivists do not need to ground every legal rule in perfectly general moral or normative facts. The best arguments for anti-positivism, we shall see in a moment, are compatible with the legality of some rules being partly grounded in minimalistic moral features and particularistic normative truths (the existence of some reasons for some agents to follow the relevant rules).

I have said nothing so far about instances of "derived" legality that are not themselves conventionally embraced. Positivists maintain that the higher-order rules (of recognition or otherwise) need to be conventionally accepted in order to be legal. But perhaps the rules derived from the rule of recognition can be

There are different ways of getting to the result that whenever you have a desire to $\phi$, you have some reason to $\phi$. One way is to be a kind of hedonist (or desire-satisfaction theorist) who embraces a first-order normative view concerning what there is reason to do-namely, to satisfy one's desires. This kind of view does not necessarily explain why there are those reasons (cf. Williams, "Internal and External Reasons"). Another route to the conditional claim involves embracing an analytic or reductive claim about what it is for there to be a reason to do something. This kind of Humean holds that what it is for some consideration to be a reason for you to do something is (roughly) for it to explain why doing it would satisfy your desires (cf. Schroeder, "The Humean Theory of Reasons"). Scanlon's discussion of the distinction is helpful (see Scanlon, Being Realistic about Reasons). For present purposes, I can remain neutral between these two views, though I accept only the first-order substantive claim, which I take to be supported by the many instances in which an agent's desires to $\phi$ and reasons to $\phi$ co-travel. Thanks to an anonymous reviewer for pushing me to make this explicit.

The appeal of etiquette norms seems to be a function of this mode of concern. These reasons (e.g., to doff one's hat in certain social situations) are, as before, appreciable from a motivational perspective which involves concern for conventions or respecting how we do things around here. For a systematic treatment of the normativity of formal accepted standards, see Woods, "The Authority of Formality." 
forgotten, or widely ignored, or even widely ridiculed, and yet remain legal. ${ }^{26}$ Could a morally defective rule derived from a forgotten statute not serve as an easy counterexample to anti-positivism, since there are no normative reasons to follow such a rule that might be derived from its conventionality (or its moral optimality)?

There are two observations to make about forgotten, morally suboptimal, derived rules. First, there appear to be weak normative reasons for some agents to follow even these rules. The normative reasons for following such rules may be entirely parasitic on the normative reasons for following the higher-order rules of a legal system, which are accepted in the community by, at the very least, its legal officials. We can represent rules as functions which take circumstances to actions or outcomes, with higher-order rules specifying outcomes in terms of other rules. On a plausible view of what it is to follow a rule or be guided by it, following a rule involves adopting a practical stance of being willing to bring about the outcome specified by the rule in the relevant circumstance insofar as the outcome's realization depends on one's practical attitudes. ${ }^{27}$ Let us grant that acceptance of a higher-order rule by the judges of a legal community generates, at a minimum, desire-based "Humean" reasons for judges to follow it. But then there are instrumental reasons for these judges to follow the derived rules. Following the derived rules is the outcome the higher-order rules of recognition and enforcement call for. Even if the derived rule has as little to do with a judge's actual situation as a rule requiring companies to make their prospectuses available to investors, the judge can follow it in the relevant sense, where this might involve being willing to enforce the rule, or being willing to obey it in the (counterfactual) circumstance of owning a company. ${ }^{28}$

I credit an anonymous reviewer for the objection.

27

There is no forcing the positivist to accept my account of what it is for officials to "accept" the rule of recognition. But I think any plausible version of positivism will take the shape I have described. A view according to which all it is to accept a rule of recognition is to adopt a way of talking (a way of using the term "law") seems to me to miss an enormous amount of what it is to be a judge (or a legal official) who has taken an oath of fidelity to law. It is notable that positivists have been less than transparent in their account of the nature of rules and rule-following. E.g., Hart declares "the idea of a rule" is one "without which we cannot hope to elucidate even the most elementary forms of law," but takes rules as primitive (The Concept of Law, 8, 82-86). He tells us what necessarily follows from their existence, what makes a rule a social rule, and so on. But he does not give us an account of their general nature. So, it is reasonable for me to make some assumptions here (and I make them in good faith: they reflect my considered view on the nature of rules and rule-following).

Cf. Gibbard's contingency plans (Thinking How to Live). This explains why even so-called power-conferring rules are ones which can be followed by judges who accept them indirectly. Following a power-conferring rule does not require exercising the power it confers. 
Admittedly, the derivative (or instrumental) reasons for following a derived rule will be especially weak in some cases, when there are not independent moral reasons or reasons having to do with the rule's wider acceptance in the community which militate directly in favor of following the rule. The example of a morally suboptimal rule derived from forgotten statutes nicely illustrates this. But-and this is the second notable fact about this general class of rules-the legality of forgotten statutes is not straightforward (later I explain what makes for an "easy" counterexample to anti-positivism). Judges often question the legal relevance of forgotten statutes, or old cases that no one cites anymore, treating the rules derived from them as possessing a kind of degenerate legality. For example, under the doctrine of "desuetude," the legality of statutes and doctrines can lapse due to neglect. One of the most ancient maxims of the common law, cessante rationae legis, cessat at ipsa lex, underpins this doctrine: "the reason for a law is the soul of the law, and if the reason for a law has changed the law is changed."29 Accordingly, even positivists should feel some pressure to accommodate or explain why the relevant class of rules represents cases of marginal legality at best.

One way to follow a power-conferring rule is to help confer the power when the rule calls for it. E.g., a power-conferring rule of the common law of contracts says: "if someone makes a promise backed by 'consideration' (where this is roughly a matter of the promise being induced in the right sort of way), the promisee has the power to enforce it." This rule confers a power on the promisee to enforce the promise in court. Judges follow this rule. The promisee takes advantage of it. I realize that there is some pressure from Hart (The Concept of Law) and others (and contra Austin, The Province of Jurisprudence Determined, and Kelsen, Pure Theory of Law) to construe power-conferring rules as not being "directed at officials." The debate seems to me to misconstrue the nature of rules. Rules do not "direct" themselves to individuals. There are just different ways for different individuals to follow a rule. Power-conferring rules should be construed as calling for an outcome where an agent is treated in certain specified ways by others and perhaps herself. What does it mean to follow such a rule practically? The answer depends on how we flesh out the outcome and on who is doing the following. There is no reason to think the outcome cannot require officials (among others) to act in certain ways with respect to the agent (e.g., enforce a promise made to the empowered agent).

So, there are normative reasons to follow power-conferring rules: at the very least, some agents (e.g., judges and other officials) have some reason to follow the rules, for the reasons I give in the case of "derived" rules. A juridical commitment to the rule of recognition which recognizes the power-conferring rules as law entails some degree of commitment to the derived rule. But in standard (easier) cases of legality, there will be independent noninstrumental normative reasons to follow the derived power-conferring rules, e.g., that the rule promotes general welfare, or because the rule is widely followed in the community. Thanks to an anonymous reviewer for pushing me to make my view on power-conferring rules explicit. 
The claims I have made about the moral and broadly normative reasons agents have to follow the wide range of morally defective rules we encounter in legal systems are consistent with a robustly objectivist metaethics and a non-relativistic normative ethics. ${ }^{30}$ There is no need for the anti-positivist to think that moral facts, like the fact that there is a moral reason to follow rules widely accepted and obeyed in order to promote one's own interests, are themselves fully grounded in social facts. The social facts would then fully explain the legality of rules and their relevant moral features. The anti-positivist can instead treat the moral facts as irreducible. That there is a moral reason to follow a conventionally embraced rule might be partly grounded in non-moral facts, like the rule's conventionality. But it is also grounded in a pure moral fact: the moral principle that if following a rule promotes your interests, then there is some moral reason to follow it. ${ }^{31}$ It is this latter moral fact that is part of the explanation for the legality of rules and is not itself grounded in a social fact. And as far as first-order ethical commitments go, thinking that there are reasons to satisfy desires or moral reasons of self-protection does not entail denying the possibility of a wider range of objective goods that come apart from the desires and interests of agents. ${ }^{32}$

An anonymous reviewer invites an account of the difference between robust and "thin" (or merely "formal") normativity, and asks whether the reasons I have identified for following legal rules are robustly normative. This is a subtle issue. But as far as I understand the thin/robust distinction, I take the reasons I have identified to be metaphysically robust-as robust, at any rate, as moral reasons. The reasons of self-protection and reasons to follow conventions just because one cares about conventionality are determinates of a single determinable (reasons). They are as irreducibly real as moral reasons to promote aggregate well-being, and our ontology must make room for them. One interesting distinction in the realm of reasons is not the thin/robust distinction (or a distinction concerning the nature of normativity), but the fact that some reasons reflect moral concerns and others do not. The moral character of a reason appears to be a function of the motivations necessary to appreciate the force of the reason (nonnormatively described, e.g., impartial, and welfarist motivation, in the precise sense I gave earlier). And moral reasons have a unique grip on some of us, where this is a descriptive psychological claim. That is the only sense in which the nonmoral reasons are not "robust." Talk of robust normativity may be an oblique way of talking not about the metaphysics of normativity, but about our special sensitivity to moral reasons, and the fact that we assess other schemes of value against moral standards. Scanlon, What We Owe to Each Other, 36-40.

Ethical objectivists sometimes deny that reasons to do as one desires are grounded in facts about our desires, which is compatible with my view. Scanlon, What We Owe to Each Other, ch. 1, e.g., suggests that all cases of desires seeming to give us reasons are really cases where the reason is grounded in some non-motivational fact (e.g., the prospective pleasure to be gained from satisfying the desire). For my purposes, all I need is the plausible conditional claim that whenever (or, at least, typically when) one has a desire to $\phi$, one has some reason to $\phi$. It is true that my view rules out an extreme ethical objectivism on which even this 


\section{INCLUSIVE ANTI-POSITIVISM}

There are moral and broadly normative reasons for various agents to follow rules whose legality presents an extensional challenge for anti-positivism. The next step in a defense of anti-positivism is an account of why an anti-positivist might plausibly hold that the identified normative facts ground the relevant instances of legality. The aim is not to systematically defend the resulting strain of anti-positivism. It is to state the view's defining commitments with sufficient clarity to show that there is no obvious reason why it could not be true, and to make a prima facie case for it in terms of the central motivations for being an anti-positivist-enough of a case, at any rate, to secure the logical point that there is a viable strain of anti-positivism which avoids the most famous objection to anti-positivism.

I will begin by stating the general position, writing as if it is true to make exposition easier, before motivating it and handling objections. A helpful concept with which to start is that of an evaluative perspective marked by special solicitude for conventional ways of doing things but also moral concern. ${ }^{33}$ Such "mixed" evaluative perspectives are very familiar. We occupy such a perspective when, for example, we weigh our subjective attachments (say, special concern for a loved one, or for one's life projects) against impartial, other-regarding moral considerations in determining whether a course of action is justified relative to the totality of our values. ${ }^{34}$ Enculturation in the legal professions is a way of becoming acquainted with a distinctive way of caring, a distinctively juridical sense of what is valuable, involving high respect for conventionality (a commitment to conventional ways of doing things for convention's sake) as well as moral concern (e.g., a commitment to general welfare, self-protection, and so on).

This juridical mode of concern may appear fetishistic from the moral point of view. It involves, among other things, caring about tradition and the way we do things around here as though it mattered intrinsically. But that does not make the values that the juridical evaluative perspective makes visible "as if" or "imposter" values. The values are, at worst, morally bad. ${ }^{35} \mathrm{And}$, as I emphasize below,

conditional claim is false. But perfect neutrality on all ethical matters can hardly be foisted on anti-positivists.

Williams famously offers an account of normative reasons in terms of what he calls an agent's "subjective motivational set"- the totality of the agent's commitments, desires, goals, etc. allowing motivational changes based on sound deliberation ("Internal and External Reasons"). I intend the notion of an evaluative perspective to be very close to Williams's notion of a subjective motivational set.

Williams, Moral Luck.

On the normativity of moral versus nonmoral value, see notes 13 and 22 above. 
what I am calling the juridical evaluative point of view is not entirely fetishistic-it is partly constituted by recognizably moral values, involving, for example, concern for general well-being.

Consider a normative property of rules defined in terms of this evaluative perspective: that of a rule's being normatively well supported to a high enough degree, where what counts as a relevant normative reason favoring the rule is based on the evaluative perspective in question, involving concern for the social and moral characteristics of rules. ${ }^{36}$ Being normatively well supported to a high enough degree is a threshold normative property. If a rule meets the justificatory threshold, it does so in virtue of the sum of social and moral considerations favoring a rule, not a precise blend. In some cases, a rule will meet the relevant threshold despite weak moral support. When a rule is strongly conventional, its strong "social support," which consists in the normative reasons legal officials and others have to follow the rule just because it is conventional (because of their attitude of rule acceptance and commitment to following conventions), can be understood as compensating for its extremely weak moral support. ${ }^{37}$ Not in a moral sense. But in the special normative sense I am suggesting reflects the distinctive evaluative perspective under consideration. ${ }^{38}$ The robust or optimific moral features

36 I intend "normative reason" and the favoring relation here in roughly the same sense as Scanlon when he speaks of "considerations counting in favor" (What We Owe to Each Other).

37 We should distinguish the social property of being conventionally embraced from the normative reason to follow the rule that is (normatively) grounded in this social property (what I am calling "social support"). There are normative reasons that are not grounded in the social property but that depend in a different sense on the social property: e.g., the moral reasons I highlighted earlier (of impartial self-protection, among others). A rule's conventionality does not matter intrinsically relative to these moral reasons. What matters intrinsically is the good of self-protection. As discussed in section 2, the relevant social facts also entail (where this entailment has a normative flavor) desire-based "Humean" reasons to follow a rule, relative to which the rule's conventionality is intrinsically normatively relevant. The latter are reasons one would be sensitive to were one particularly concerned with respecting conventions for convention's sake (as legal actors often are, perhaps because of internalized professional obligations). Legality is a function of the sum of these various types of supporting considerations for following a rule, which may bear differently on different agents.

38 If one values respecting conventions highly enough, moral considerations never trump institutional support. Just because moral considerations are relevant from the legal evaluative point of view, this does not mean they have their usual peremptory force. No doubt the legal evaluative perspective may be criticizable from the moral point of view. It may be morally perverse. But that is true of most evaluative perspectives that are not exclusively concerned with morality. And there may be moral reasons of a rule-consequentialist sort which favor some agents cultivating this form of concern, and a corresponding sensitivity to the relevant reasons. 
of certain rules can similarly compensate for their weak social acceptance (in the terminal case, acceptance by a single moral agent). In other words, a morally optimific principle may meet the relevant threshold of being sufficiently favored despite its weak social acceptance in the community.

There is a viable strain of anti-positivism which identifies the property of being law with the aforementioned normative property of rules (being normatively well supported to a high enough degree) and that promises to be counterexample proof. The property identification entails a general grounding thesis:

General Grounding Claim: Given any legal rule, the rule's legality is grounded in whatever normative reasons there are for agents to follow the rule (where the range of relevant normative reasons is defined in terms of the juridical evaluative perspective).

From this general grounding thesis, more particular grounding claims follow, including that instances of morally abhorrent legality (the Fugitive Slave Act) are partly grounded in what weak moral reasons agents have to obey the rules, together with normative reasons derived from a juridical commitment to following a convention for convention's sake. If a rule surpasses the threshold level of normative support, this fact will always be grounded in whatever normative reasons agents have for following the rule, whether they derive from an attachment to conventions, or the self-protective interests of persons, or general welfare. Compare: the fact that the square is over forty percent blue is grounded in facts concerning the square's blueness - every inch of blueness grounds the threshold fact. Accordingly, a defense of inclusive anti-positivism turns on a defense of the general grounding thesis (and the property identification), not particular grounding claims, concerning, for example, the legality of the Fugitive Slave Act.

A defense of the general grounding thesis does not need to be based on brute intuition, or rational insight into the nature of law, or anything so remarkable. Inclusive anti-positivism's core commitments can be motivated by appeal to considerations of theoretical power and adequacy. It is notable, first, that the view, with its defining commitments clarified, does not show any signs of obvious error or internal incoherence. Second, it amounts to a position on legality that is clearly distinguished from positivism. Positivism and inclusive anti-positivism differ in their first-order implications concerning which rules are law; in their second-order explanations concerning why the relevant rules are law; and in their take on the essence or nature of the property of legality. According to inclusive anti-positivism, the concept of law is the concept of an objective normative similarity across rules which possess a variable mix of social and moral properties. The relevant similarity consists in the normative well-supportedness 
of these rules relative to the values characteristic of a distinctive (if vaguely defined) juridical evaluative perspective. ${ }^{39}$ Positivists rarely make their views concerning the nature of the legal property explicit. But no positivist, as far as I can tell, construes the property of legality as essentially identical to a bona fide normative property.

The explanatory differences are related to this essentialist difference. The least controversial instances of legality are ones involving legal rules that are both conventionally embraced and morally optimific. These rules are law, according to the inclusive anti-positivist, because they clearly surpass the threshold of normative well-supportedness. By contrast, the positivist claims these rules are law just because they are conventionally embraced or because they are derived from rules of recognition that are conventionally embraced.

The views differ extensionally. There exists a possible jurisdiction where a morally optimific principle-say, a principle banning the torture of animals in factory farms - enjoys very little conventional support. Furthermore, the principle cannot be derived from any conventionally embraced rule of recognition in the jurisdiction. The inclusive anti-positivist declares the principle (marginally) legal, whereas the positivist, whether inclusive or exclusive, denies the principle's legality. ${ }^{40}$

In addition to being sharply distinguished from both inclusive and exclusive varieties of positivism, inclusive anti-positivism seems eminently defensible based on the types of considerations which motivate anti-positivism generally. There is considerable irony in the fact that the best arguments for anti-positivism turn out to be extensional. Although rarely characterized as such, the classic arguments which appeal to judicial behavior emphasize an extensional inadequacy of positivism. ${ }^{41}$ Judges routinely classify rules that enjoy strong moral support as law even if there is not a widespread convention within the jurisdiction of following the rule. ${ }^{42}$ And they appear to be doing so on conceptual grounds alone,

39 I am intentionally vague about several aspects of the juridical evaluative perspective, including the precise relationship between social and moral support. We should not aspire for greater determinacy in our account of a concept than its nature warrants. As I explain below, the imprecision has an explanatory upshot.

I discuss whether this extensional difference generates an "easy" counterexample in section 4 .

41 Dworkin, “The Model of Rules" and "Hard Cases"; Radbruch, "Vorschule der Rechtsphilosophie."

Additionally, judges justify broader interpretive methodologies by appeal to moral considerations, and not as an indirect means of identifying the socially embraced methodology for interpreting law (Dworkin, Law's Empire). For positivist rejoinders, see Raz, The Authority of Law, ch. 9, and Waluchow, Inclusive Legal Positivism. We do not have to assume that Dwor- 
because there is no obvious social convention within jurisdictions which authorizes such behavior by judges. For instance, Dworkin provides various examples of common law judges invoking general moral principles as law, and without citing custom, including, for example, the principle that "courts will not permit themselves to be used as instruments of inequity and injustice." ${ }^{43}$ Dworkin argues that, in determining the content and application of these principles, judges view themselves as figuring out the law, but the content of these principles cannot be grounded in conventionally embraced rules.

In fact, judges do not simply make first-order judgments ascribing legality to morally optimific rules. They make second-order judgments about why these rules are legal-judgments that are prima facie incompatible with positivism. For example, in the famous contracts case of Bailey v. West, the court explains that a benefactor who voluntarily confers a benefit without the explicit consent of the beneficiary is sometimes owed remuneration where the obligation is grounded in a "law of natural immutable justice." The court does not say that the reason why the relevant principle of justice concerning fair compensation is law is that it is socially treated as such, or that there is a convention of treating basic principles of justice as law, or that the rule is derived from conventionally embraced rules. Judges describe natural justice as a fundamental source of law. ${ }^{44}$ Taking the phenomenon at face value, judges treat the legality of morally optimific principles as not needing to be further explained in terms of conventions or anything social. It is easy to multiply similar examples. ${ }^{45}$

If we take judicial intuitions about the legality of rules seriously, positivism seems falsified by the existence of morally well-supported rules that are recognized as law simply because they are morally well supported. Positivists have offered various responses to this extensional challenge, none of which seem to

kin prevails over his critics (though I think he does) in order to show that inclusive anti-positivism of the sort developed in this section can be motivated based on considerations that have traditionally inspired anti-positivists.

Dworkin, "The Model of Rules," 20-25.

E.g., see Hammond v. Allen, 2 Sumn. 387 ; 11 F. Cas. 382 (1836). See also Blackstone, Commentaries on the Laws of England, vol. 1, 69-70.

5 A systematic catalog of all relevant cases illustrating this phenomenon is reserved for future work. A quick search of all state and federal US cases and pre-1777 English reports for uses of "laws of natural justice" (and various equivalents) returns 1,115 hits. A search for "moral law" or "natural law" returns 4,184 hits. And a search for "principles of justice" returns over 10,000 hits. The evidence is not limited to common law or modern jurisdictions. There are examples across history; for example, from pre-Christian Rome. Pomeroy, A Treatise on Equity Jurisprudence, sec. 8, describes pre-Christian Roman magistrates who treated the stoic theory of morality as an original source of law, discovered and not invented. Pomeroy, it is worth emphasizing, has no anti-positivist axe to grind. 
me to be very plausible. One response, favored by inclusive positivists, insists on a social conventional explanation for why judges recognize morally optimific principles as law. ${ }^{46}$ There is a conventionally embraced rule of recognition, we are told, in the relevant jurisdictions that calls on judges to recognize morally optimific principles as law. But as a matter of social fact it is highly controversial whether the conventionally embraced rule of recognition in common law jurisdictions licenses the move from the moral optimality of a rule to its legality. We must distinguish behavioral regularities from conventions. Judicial willingness to classify moral principles as law may be a regularity. But it is not self-conscious (social) rule following — a fact apparent from considerable disagreement among judges about whether local custom authorizes appeals to morality in the discovery of law. Judges sympathetic to positivism describe such conduct by their peers as "judicial usurpation" of the administration of morality. ${ }^{47}$ Meanwhile, judges friendly to the "laws of natural justice" acknowledge the disagreement and deem their peers mistaken, not about the conventions in place in the jurisdiction but about law's conceptual connection to morality. The (inclusive) positivist's account of the practice in terms of a rule of recognition embraced by legal officials is rendered, at a minimum, doubtful in light of such disagreement.

Furthermore, the inclusive positivist's response to the challenge runs up against the second-order explanations these judges give for why morally optimific rules can be law, explanations which suggest a fundamental conceptual identification of law with morality, not an indirect or derivative legality. So, the positivist owes us an explanation for why interpreters of law are mistaken. Positivism entails a significant error theory concerning experts to whom our community defers on questions of law.

Positivists sometimes charge judges as engaged in a kind of pretense or outright deception. We are told judges friendly to the "laws of justice" are engaged in law-making but are pretending to discover preexisting law. But an uncharitable explanation seems implausible in the case of, say, pre-Christian Roman magistrates who deemed the stoic theory of morality a source of Roman law, discovered and not invented. ${ }^{48}$ If these judges had any political reasons to lie about the grounds of law, those reasons are not obvious. ${ }^{49}$ In any event, uncharitable interpretation should be a kind of fallback option, if there is no better theory of

46 Waluchow, Inclusive Legal Positivism.

47 See, e.g., Orr v. Quimby, 51 N.H. 590, 646 (1874).

48 Pomeroy, A Treatise on Equity Jurisprudence, sec. 8.

49 Dworkin makes a similar point about common law judges (Law's Empire). For a positivist response, see Marmor, Philosophy of Law, 90. The implausibility of an explanation which appeals to juridical fraud seems especially apparent in the case of ancient legal societies. 
the nature of our legal concept that can vindicate the judgments of legal experts. Fortunately, a theory which avoids this kind of undermotivated lack of charity is in the offing.

Anti-positivists have undermined the force of the juridical considerations by declining to follow the extensional logic where it leads. As noted, anti-positivists have tended to dismiss or altogether ignore judicial willingness to classify morally abhorrent but strongly conventional rules as law. A truly extensionally adequate theory of law, one that takes seriously the extensional intuitions of experts, would be consistent not just with their willingness to classify on conceptual grounds alone strongly moral but weakly conventional principles as law, but also abhorrent laws like the Fugitive Slave Act.

Inclusive anti-positivism promises to be consistent with both strands of judicial behavior. According to the inclusive anti-positivist, judges will recognize as law morally optimific but weakly conventional rules as well as strongly conventional but weakly moral rules, because these two types of rules represent different ways of meeting the normative threshold of being sufficiently worth following from the juridical evaluative perspective, where conventions matter greatly but so does the morality of rules. This seems to me to be the main virtue of the strain of anti-positivism I have described: it achieves a better extensional fit than positivism as well as traditional versions of anti-positivism, without devolving into a gerrymandered theory of law.

This brings us to a second theoretical virtue: the view captures and explains the unity of our concept of law. The inclusive anti-positivist does not purchase extensional adequacy at the disjunctivist's price of saying legality is sometimes wholly grounded in social properties and in other cases wholly grounded in optimific moral properties. This would be implausible because, in general, non-disjunctive phenomena do not have as independent full grounds two entirely distinct types of facts. Social/empirical facts about a rule's conventionality and moral facts about a rule's being morally favored are intuitively quite different propositions. ${ }^{50} \mathrm{~A}$ non-disjunctive type of fact cannot be both wholly grounded in B-facts and wholly grounded in C-facts, when B-facts and C-facts are entirely dissimilar. The disjunctivist might try to defend her claims on semantic grounds, arguing that the term "law" is polysemous: we use it to refer to two very different kinds of phenomena. But if "law" were like the English word "bank," we would expect to find some natural language that disambiguates the two senses by giving them different names (like "berge" and "banque" in French). We do not find 
this disambiguation in the case of "law." On the contrary, we find that the variety of legal rules exhibits an appearance of unity. ${ }^{51}$

Inclusive anti-positivism vindicates this appearance. The concept of law is the concept of an objective similarity class. It is the concept of a normative similarity possessed by a set of rules, appreciable from an evaluative perspective requiring enculturation in the legal profession. Relatedly, it is always a combination of moral and social properties of rules that grounds their legality, although the mix might differ in individual cases, just as an object's redness can be grounded in its being one of a range of determinate shades of red, with variable hue, chroma, and brightness. Another helpful comparison may be found in what Kovacs calls "aggregative cluster concepts" like "is bigger than," which combines volume, length, and mass but without a precise trade-off function. ${ }^{52}$ The analogy with redness and other properties which give rise to an objective similarity or natural unity is intended very seriously. A theory of law is attractive to the extent that it identifies legality with a property that can serve a useful theoretical role on account of its nature and that can explain how the moral and social characteristics of rules work together in generating law. Legality, as construed by inclusive anti-positivism, is just such a property. It is the bona fide normative property of rules one would be sensitive to were one's evaluative perspective marked by a uniquely high solicitude for conventional ways of doing things but also recognizably moral values.

Inclusive anti-positivism incorporates a large part of the content of morality into law. One of the principal motivations for being an anti-positivist is the possibility of a moral critique and improvement of law from an internal-to-law perspective. It is always possible to morally criticize a system of rules from the external point of view. One might morally object to the rules of Monopoly because they encourage acquisitiveness. It is quite another thing to critique a system of rules using its own rules. The inclusive anti-positivist can say that while morally abhorrent rules were law in Nazi Germany, so was a rule requiring respect for human dignity, even though it was not recognized as such. The rule had enough morally going for it that it arguably met the legal normative threshold. ${ }^{53} \mathrm{Had}$

51 Hart, The Concept of Law, ch. 1. To be sure, many of our concepts are revealed to be gerrymandered or defective upon investigation. But the appearance of unity should be taken seriously as a theoretical starting point. Its vindication constitutes a theoretical virtue.

52 Kovacs, "The Deflationary Theory of Ontological Dependence."

53 I am intentionally vague about several aspects of the relationship between social and moral support: e.g., how the supportive reasons are individually weighted (how much social support matters compared to moral support in the additive function which determines whether the legal normative threshold is reached) and the precise threshold of normative well-supportedness that suffices for legality. I have not taken a stand on these issues because, for one, 
it been recognized as law by Nazi jurists, there might have been greater official resistance against the Third Reich. (That the laws of a regime can conflict is of course a commonplace.)

The significance of a robust incorporation of morality into law is hard to overstate. Consider the perspective of a conscientious judge concerned with abiding by her distinctively legal duties. Such a judge will not rule against the law, unless authorized by law to do so. If inclusive anti-positivism of the form I have described is true, it remains possible for a judge to comply with her legal duties while striking down morally abhorrent laws for conflict with other laws that are morally optimal even if weakly conventional. An account of law's nature which secures on conceptual grounds alone a moral critique of law that is, at the same time, a legal critique is a view worth taking seriously. ${ }^{54}$

It is true that even the positivist can secure an internal-to-practice moral critique of a legal system, provided the right sort of conventional rules are in place. ${ }^{55}$ But the availability of such a critique, given positivism, is socially contingent. The existence of the relevant conventionally embraced legal rules in modern jurisdictions which license moral critique is controversial. And the anti-positivist's central intuition is that it is an essential feature of legal systems that they render moral critique and improvement of law by jurists lawful. To put it differently, the lawfulness of such a critique in any jurisdiction seems intuitive before we learn anything about what conventions are in place in the jurisdiction.

The above remarks are not intended as a substitute for a full-fledged argument for inclusive anti-positivism. We have secured, however, the beginnings of an argument at the very least. Inclusive anti-positivism's extensional power (its compatibility with the judgments of experts concerning the laws of a community), its consistency with the apparent unity of the concept of law, its compatibility with a moral critique of law that is at the same time a legal critique, suggests a

I do not have a refined enough sense of the juridical evaluative perspective. But the more important reason for embracing vagueness is that it results in an explanatorily powerful theory of law. The vague, imprecise nature of the juridical evaluative perspective delivers a nice account of why we encounter disagreement at the normative margins, but convergence at the core-that is, agreement about the legality of rules that are both conventional and morally optimal. The phenomenon of concepts/properties constituted by imprecise functions is utterly familiar. That is the point of analogizing with "is bigger than" and "red." Legality is of a piece with other determinables with vague natures which nevertheless exhibit a natural unity.

This is not just wishful thinking. Arguably, judges behave as though an internal-to-law moral critique is possible, and not because a convention authorizes such behavior (Dworkin, "Hard Cases"; Atiq, "Legal Obligation and Its Limits").

Thanks to an anonymous reviewer for the objection. 
plausible form of anti-positivism worthy of serious consideration. I suspect that the case for inclusive anti-positivism is even stronger than I have had occasion to explore here. ${ }^{56}$ But my present aim has been a modest one, limited to framing and illuminating a novel hypothesis in the theory of legality in a way that shows that a bit of orthodoxy in legal philosophy concerning one of the most powerful objections to anti-positivism is mistaken. Anti-positivism is not per se vulnerable to easy counterexamples from the positivist.

\section{WHAT ABOUT FALSE POSITIVES?}

There are two kinds of counterexamples one can mobilize against a view. There are false negatives-cases of manifest legality that the view cannot capture. But there might also be false positives-rules that the view entails are law but that do not appear to be. Even if I am right that inclusive anti-positivism is invulnerable to extensional challenges based on false negatives, perhaps grounds for an extensional challenge remain. Is it not obvious that a rule requiring respect for human dignity failed to be law in Nazi Germany?

The focus on false negatives is well motivated. An extensional challenge based on the denial of the legality of weakly conventional yet morally optimific moral principles would be far less compelling than a challenge based on the legality of Nazi rules. Everyone agrees that the legality of rules is often obscure. Interpreters of law often struggle with the evidence to determine what the law is on hard legal questions. ${ }^{57}$ The obscurity of law explains failures to appreciate the legality of rules. ${ }^{58}$ By contrast, it is much harder to explain away persistent positive intuitions of a rule's legality. The property of being law is not the kind to be mistakenly detected by a large number of reasonable interpreters of law. It

The imprecise nature of the juridical evaluative perspective may explain why we encounter disagreement with respect to cases of law involving rules which score highly in terms of social support but not moral support and vice versa, as well as general agreement about the legality of rules which enjoy both forms of normative support. Everyone agrees about the legality of rules that are both strongly conventional and morally optimal, because these rules easily surpass the threshold of normative support required for legality. Cases of marginal legality are more likely to inspire disagreement. Dworkin, "Hard Cases."

58 The inclusive anti-positivist can explain why the legality of morally optimific (but weakly conventional rules) might be obscure. The legality of rules is a function of their meeting a vague normative threshold. It is harder to recognize the legality of rules that just barely meet the threshold because they score well along a single evaluative dimension. If morally optimific but barely conventional rules are law, they are marginal cases of legality at best. 
is hard to see, in other words, why there would be persistent illusory manifestations of legality.

There is another difference between the positive and negative extensional challenge. The mere fact that inclusive anti-positivism offers a different account of law's extension than positivism is hardly a problem. The problem arises if the positivist can mobilize theory-neutral intuitions of legality against the anti-positivist. That is what makes the false negatives so damning. Legal theorists who have thought long and hard about the legality of rules independently of the philosophical debate strongly judge that the Nazis had a legal system, and that the Fugitive Slave Act was law. So, to have a viable theory, anti-positivists should worry about accommodating these cases.

It is much harder to build a theory-neutral case against the anti-positivist based on the alleged false positives. Judges unexposed to the positivism/anti-positivism debate act as if moral principles are law. Even some positivists (inclusive positivists) agree that morally optimific principles can be (and in many jurisdictions are) law. They just have a different account of why, fundamentally, they are law-namely, in terms of an alleged convention within the jurisdiction allowing judges to treat morally optimific principles as law. The case where inclusive positivism and inclusive anti-positivism deliver incompatible verdicts concerns morally optimific (yet weakly social) rules in a jurisdiction where no widely accepted convention exists of treating morally optimific principles as law. And it is implausible that this extensional dispute can be resolved on pre-theoretical grounds alone. The case is too contested, independently of philosophical argument, for it to be decided based on the deliverances of pre-theoretical intuition. This is not a decisive showing that the inclusive anti-positivist is right about the case. It is a decisive showing, I submit, that there are no easy counterexamples to legal anti-positivism. ${ }^{59}$

Cornell University eha47@cornell.edu

This paper was inspired by and refined through conversations with Andrei Marmor, with whom I co-teach a seminar in legal and moral philosophy, and to whom I owe a debt of gratitude. I received exceptionally helpful feedback, also, from two anonymous referees for Journal of Ethics and Social Philosophy. Thanks, finally, to Nat Tabris, Gideon Rosen, Jack Woods, Kevin Clermont, and Brad Wendel, for their helpful comments and discussion. 


\section{REFERENCES}

Alexy, Robert. "Legal Certainty and Correctness." Ratio Juris 28, no. 4 (December 2015): 441-51.

Aquinas, Thomas. The Summa Theologiae of St. Thomas Aquinas. 2nd and rev. ed. Translated by Fathers of the English Dominican Province, 1920.

Atiq, Emad H. "Legal Obligation and Its Limits." Law and Philosophy 38, no. 2 (2019): 109-47.

- "Supervenience, Repeatability, and Expressivism." Noûs (forthcoming). Published ahead of print, April 1, 2019. https://doi.org/10.1111/nous.12284.

Austin, John. The Province of Jurisprudence Determined. Cambridge: Cambridge University Press, 1995.

Blackburn, Simon. Spreading the Word. Oxford: Oxford University Press, 1984.

Blackstone, William. Commentaries on the Laws of England, vol. 1. Oxford: Clarendon Press, 1765.

Coleman, Jules. The Practice of Principle. Oxford: Oxford University Press, 2001.

Dworkin, Ronald. "Hard Cases." Harvard Law Review 88, no. 6 (April 1975): 1057-1109.

- "The Law of the Slave-Catchers." Times Literary Supplement, December 5, 1975 .

- Law's Empire. Cambridge, MA: Harvard University Press, 1986.

. "The Model of Rules." The University of Chicago Law Review 35, no. 1 (1967): 14-46.

- "'Natural' Law Revisited." University of Florida Law Review 34, no. 2 $(1982): 165$.

Finnis, John. Natural Law and Natural Rights. Oxford: Oxford University Press, 1980.

Gibbard, Allan. Thinking How to Live. Cambridge, MA: Harvard University Press, 2003.

Greenberg, Mark. “The Moral Impact Theory of Law." Yale Law Journal 123, no. 5 (March 2014): 1118-1625.

Hare, R. M. The Language of Morals. Oxford: Clarendon Press, 1952.

Hart, H.L.A. The Concept of Law. 2nd ed. Oxford: Clarendon Press, 1994.

Johnston, Mark. "The Authority of Affect." Philosophy and Phenomenological Research 63, no. 1 (July 2001): 181-214.

Kelsen, Hans. Pure Theory of Law. 2nd ed. Berkeley, CA: University of California Press, 1960.

Kovacs, David Mark. "The Deflationary Theory of Ontological Dependence." The Philosophical Quarterly 68, no. 272 (July 2018): 481-502. 
Little, Margaret Olivia, and Coleen McNamara. "For Better or Worse: Commendatory Reasons and Latitude." In Oxford Studies in Normative Ethics, vol. 7, edited by Mark C. Timmons, 138-60. Oxford: Oxford University Press, 2017. Marmor, Andrei. Philosophy of Law. Princeton: Princeton University Press, 2011. - Social Conventions. Princeton: Princeton University Press, 2009.

Mavrodes, George I. "Conventions and the Morality of War." Philosophy and Public Affairs 4, no. 2 (Winter 1975): 117-31.

Moore, G. E. Principia Ethica. Cambridge: Cambridge University Press, 1962.

Muñoz, Daniel. "All Reasons Are Moral." Unpublished manuscript.

Pomeroy, John Norton. A Treatise on Equity Jurisprudence. San Francisco: Bancroft-Whitney Company, 1907.

Radbruch, Gustav. "Vorschule der Rechtsphilosophie." In Gesamtausgabe, edited by Arthur Kaufman. Heidelberg: C. F. Müller Verlag, 1990.

Rawls, John. Political Liberalism. New York: Columbia University Press, 1993.

Raz, Joseph. The Authority of Law: Essays on Law and Morality. Oxford: Oxford University Press, 1979.

- Engaging Reasons: On the Theory of Value and Action. Oxford: Oxford University Press, 1999.

Rosen, Gideon. "Metaphysical Dependence: Grounding and Reduction.” In Modality: Metaphysics, Logic, and Epistemology, edited by Bob Hale and Aviv Hoffmann, 109-36. Oxford: Oxford University Press, 2010.

Scanlon, T.M. Being Realistic about Reasons. Oxford: Oxford University Press, 2014.

- What We Owe to Each Other. Cambridge, MA: Harvard University Press, 1998.

Schiffer, Stephen. The Things We Mean. Oxford: Oxford University Press, 2003.

Schroeder, Mark. "The Humean Theory of Reasons." In Oxford Studies in Metaethics, vol. 2, edited by Russ Shafer-Landau, 195-219. Oxford: Oxford University Press, 2007.

Shapiro, Scott. Legality. Cambridge, MA: Harvard University Press, 2011.

Thomasson, Amie L. Ontology Made Easy. Oxford: Oxford University Press, 2014.

Waluchow, W.J. Inclusive Legal Positivism. Oxford: Clarendon Press, 1994.

Williams, Bernard. "Internal and External Reasons." In Rational Action, edited by Ross Harrison, 101-13. Cambridge: Cambridge University Press, 1979.

- Moral Luck. Cambridge: Cambridge University Press, 1981.

Woods, Jack. "The Authority of Formality." In Oxford Studies in Metaethics, vol. 13, edited by Russ Shafer-Landau, 207-29. Oxford: Oxford University Press, 2018. 